\title{
LABOR'S RESORT TO INJUNCTIONS
}

\author{
EDWIN E. WITTE
}

Until quite recently, it was assumed in every discussion of the injunction question that injunctions in labor disputes were always issued against labor. It is now quite well known that labor itself sometimes makes use of this weapon to gain its ends. No study, however, has ever been made of the cases in which labor has resorted to injunctions, and widely different opinions have been expressed upon the value of this process to labor.

Strangely, the greatest enthusiasm about the use of injunctions by labor has been displayed by Law and Labor, the official publication of the League for Industrial Rights, which is the organization that has conducted the employers' side of the case in most of the great legal battles growing out of labor disputes in recent years. For several years, Law and Labor has featured cases in which labor has resorted to the courts for injunctions, and has urged labor to make greater use of this process. Somewhat similar enthusiasm has been exhibited by some of the "left wing" element in the labor movement, particularly in the recent booklet, Don't Tread On Me, ${ }^{1}$ which is a program of action for radical labor. On the other hand, the American Federation of Labor still holds the view expressed by its executive committee in its report to the 1922 convention of the Federation, that "the use of injunctions by labor is a snare and a delusion."

The facts regarding the use of injunctions by labor are quite difficult to ascertain. The great majority of such cases are unreported, and all that is available about them in printed form is contained in brief notices in newspapers or in employer or labor periodicals, which I have supplemented by correspondence with judges, attorneys, and labor leaders. Undoubtedly, there are more cases than I have been able to discover by such methods. Those found, however, are believed to be typical and, also, to include probably the great majority of all such cases.

The total number of cases that I have discovered in which labor or persons acting in behalf of labor have applied for injunctions are seventy-three, fifty-eight of them being against employees and fifteen against public officials. ${ }^{2}$ Injunctions were

\footnotetext{
1 Written by Clement Wood, Macalister Coleman, and Arthur G. Hays. Vanguard Press, 1928.

2 Injunctions have also quite frequently been sought by labor unions
} 
actually issued in only twenty-four of the fifty-eight, and in six of these the injunctions were later dissolved. In the fifteen cases directed against public officials, nine injunctions were issued, three of which were subsequently dissolved. In contrast, I have a list of above two thousand applications for injunctions against labor, about eighteen hundred of which were allowed.

The first injunction case at the suit of labor of which even specialists in this field took any note was Schlesinger v. Quinto ${ }^{3}$ in 1921. This was widely heralded as representing a revolutionary change in the attitude of organized labor toward iniunetions. In fact, however, it was not the first case of its kind. It was preceded by thirty others, the earliest of which was Worthington $v$. Waring, in which the Massachusetts Supreme Court in 1892 refused to enjoin an employer from blacklistingthe plaintiff union members. The first injunctions actually issued, however, appear to have been those taken out on behalf of the labor unions in Omaha and Denver in 1903 against the business men's associations of these cities, at least one of which was subsequently dissolved. ${ }^{5}$

It is noteworthy that in the thirty cases which antedated Schlesinger v. Quinto, of ten injunctions issued, all but four were subsequently dissolved. Since Schlesinger v. Quinto, there has been a distinct increase in the number of injunctions sought in behalf of labor, although these have been years of relatively few labor controversies; and, most significant, a much larger percentage of these actions have proven successful.

The situations in which injunctions have been sought on behalf of labor are varied. Unions have resorted to the courts to prevent lockouts and breaches of trade agreements; to secure compliance with statutory requirements by employers; to protect union pickets from violence by company guards, and union members from discharge, blacklisting, or eviction; to prevent interference with labor meetings and the enforcement of local ordinances directed against labor activities; and in yet other contingencies.

The seventy-three cases in which injunctions were sought on behalf of labor are listed in the Appendix, with citations to the sources of information. In the body of this article, only a few important and typical cases will be discussed, to furnish a basis

against rival unions and in intra-union rows, but these are outside the scope of this article.

Besides injunctions, labor unions have on $a^{\prime}$ few occasions cought damages from employers, or have applied for writs of prohibition and similar actions against public officers. All such actions on behalf of labor unions to date seem to have been unsuccessful.

3 Case 31 in Appendix.

- Case 1 in Appendix.

5 Cases 7 and 8 in Appendix. 
for an appraisal of this new development in the law of labor disputes.

Schlesinger $v$. Quinto, mentioned above, was an action brought on behalf of the International Ladies' Garment Workers Union against the Cloak, Suit \& Skirt Manufacturers Ass'n of New York City, which had adopted a resolution abrogating an unexpired trade agreement with the union. Labor appealed to the courts and was granted an injunction by Justice, now Senator, Wagner, enjoining the employers' association from breaking the trade agreement in question; and Justice Wagner was upheld on appeal by the Appellate Division. Not only did the union in this case gain a complete legal victory, but the injunction enabled it to gain its purpose. Upon issuance of this injunction, the manufacturers' association revoled its resolution abrogating the unexpired trade agreement and faithfully observed its agreement until the expiration thereof. ${ }^{\circ}$

Very similar, both in origin and its outcome, was the unreported case of Pearlman v. Millman ${ }^{2}$ in Boston in 1925. Here the fur workers' union secured an injunction against the defendant employer prohibiting him from violating a trade agreement. Upon the issuance of this injunction, the employer incorporated his business and started operations on a non-union basis. Thereupon, he was cited for contempt. He then dissolved his corporation and observed the trade agreement until it expired.

Another notably successful instance of the use of an injunction by labor is the case of the Brotherhood of Railuay \& Steamship Clerks $v$. Texas \& New Orleans $R$. $R .{ }^{8}$, which arose in the United States district court for the southern district of Texas. Judge E. T. Hutcheson, Jr., in August, 1927, directed the defendant railroad company (which is a part of the Southern Pacific system) to desist from all attempts to compel its clerks to give up their membership in the plaintiff union and to join the company union. This was followed in February, 1928, by a finding in a civil contempt case instituted by the union that the company had violated the injunction, and by the issuance of a mandatory order directing the dissolution of the company union. This injunction was made permanent in April, 1928, and recently has been sustained by the Circuit Court of Appeals in a two-toone decision. An appeal to the Supreme Court of the United Slates is now pending.

There have also occurred some notably successful actions for

\footnotetext{
6 Information upon the practical effects of this injunction was sccured from Morris Hillquit, attorney for the union.

7 Case 55 in Appendix. Information upon the results of this injunction was obtained from Benjamin Tannenbaum, attorney for the union.

${ }^{8}$ Case 62 in Appendix.
} 
injunctions against public officials. Thus, the street railway employees' union secured an order from a state court at Indianapolis in $1926^{3}$ restraining the police of that city from arresting union organizers without a warrant for crimes not committed in their presence. Prior to this injunction, the union organizers were constantly harassed by arrests on charges of disorderly conduct, vagrancy, and like offenses; there were no arrests after the injunction. Similarly, in the case of American Civil Liberties Union v. Nimmo, ${ }^{10}$ an injunction taken out during the Passaic textile workers' strike in 1926 proved effective in stopping all interference with strike meetings by the sheriff's forces, where prior thereto the sheriff had arbitrarily prohibited all strike meetings.

In other cases, however, where labor was successful in securing injunctions, they seem to have won but empty legal victories. Typical of such cases was Federated Shop Crafts v. Grcat Northern $R y$., in which an injunction was issued at St. Paul in 1923 prohibiting the defendant company from coercing the members of the plaintiff unions to join the company union. The injunction allowed was worded precisely as labor had requested, but its practical effects were nil, as the railroad company continued to deal exclusively with the company union. Of much the same practical result was the case of Carpenters' Union v. Citizens' Committee, ${ }^{12}$ in which the Illinois Supreme Court in December, 1928, held the carpenters' union of Chicago entitled to an injunction restraining the Citizens' Committee to Enforce the Landis Award from boycotting contractors who dealt with the union. Unfortunately, that decision did not come until more than five years of litigation and after the controversy which gave rise to the suit had long been ended.

Among the more important injunctions sought on behalf of labor and denied were three cases which came before the United States Supreme Court. Two of these involved an attempt by the railroad shop crafts to compel the Pennsylvania Railroad to deal with these unions in setting up adjustment boards, as directed by the Railroad Labor Board.13 The Supreme Court held the order of the Railroad Labor Board to be valid, but denied the injunctions on the ground that the Transportation Act of 1920 provided no method for the enforcement of such orders. In the third case, Anderson v. Shipowners' Ass'n of the Pacific

${ }^{\circ}$ Case 59 . Information regarding this injunction was secured from Frank P. Baker, attorney for the union.

${ }^{20}$ Case 56. Information upon the effectiveness of the injunction was obtained from Forest Bailey, Director, American Civil Liberties Union.

11 Case 43. Facts upon the practical effects of this injunction vere secured from Donald $R$. Richberg, attorney for the railroad shop crafts.

12 Case 47 in Appendix.

13 Cases 40 and 41 in Appendix. 
Coust," the Supreme Court overruled a demurrer of the defendants in a suit for an injunction to break up the so-called "hiring hall" system of employing seamen, which was claimed to result in the blacklisting of union members; but upon trial of the case, the injunction sought was denied as unwarranted upon the facts.

In all but one case in which labor has sought injunctions against blacklisting it has been unsuccessful. The one exception was a case never brought to trial. Similarly every attempt made by labor to enjoin employers from requiring their employees to sign individual non-union contracts, and all attempts to prevent school boards and other public bodies from enforcing rules barring union members from employment have proved unsuccessful. The same fate has also befallen every application for an injunction sought by labor in a cross bill or counter claim to an employers' application for an injunction. On the other hand, nearly one-half of the injunctions sought to enforce trade agreements have been allowed, as have practically every injunction sought to prevent the eviction of striking workmen from company houses or to restrain interference by employers or public officials with pickets or with strike meetings.

In considerably more than one-half of all injunction actions brought by or on behalf of labor, the injunctions sought were denied, or else were dissolved upon a hearing or by a higher court. Whether these injunctions were denied rightly or wrongly lies outside the scope of this article. The fact that a much larger percentage of injunctions have been denied to labor than to employers does not establish that the courts have been unfair to labor, and no such inference should be drawn from anything in this article. All that can be said is that labor has thus far been quite often disappointed when it applied to the courts for injunctions against employers or public officials. This, however, is not at all surprising, in view of the fact that actions of this kind are still in their infancy; moreover, the percentage of successful actions has been much greater in recent than in earlier years.

The grounds for refusing injunctions sought by or on behalf of labor have been many and varied. Most frequently such injunctions have been refused because the court found that the conduct complained of by labor was lawful. On many of the questions raised by labor in applications to the courts for injunctive relief, the substantive law is against labor. This is the principal reason for the failure of all injunctions against blacklisting, individual non-union contracts, and rules of public bodies discriminating against union members. It is also a factor limiting the use of injunctions to enforce trade agreements. In many jurisdictions the courts have never given to trade agree-

is Case 58 in Appendix. 
ments the status of binding contracts; and in such states, resort to injunctions to compel observance of trade agreements is likely to prove disappointing.

Another ground for the refusal of injunctions sought by labor against employers or public officials has been that labor did not come into court with clean hands. In any strike in which the strikers have been guilty of any acts of violence, any injunction sought in their behalf is likely to be refused upon this ground. Again, in a number of cases, it has been held that the labor unions or other organizations bringing the suit had no interest in the matter or any right to act for the workingmen in whose behalf the action was started.

For these reasons, and perhaps others, it is not likely that labor will soon be able to make as effective a use of injunctions as employers. There are certainly some cases, however, in which labor can effectively use injunctions, both to preserve the rights of its members and to embarrass employers with whom it has a controversy. In thirty-three cases, injunctions have been issued against employers or public officials in connection with labor disputes; and, while in nine of these cases, the injunctions issued were subsequently dissolved and in several other cases turned out to be wholly inefiective, not a few of these injunctions accomplished every purpose that labor aimed at in applying to the courts for equitable relief. In no case in which injunctions were subsequently dissolved, moreover, have the defendants recovered damages. This suggests that labor can without risk of damages probably procure many temporary restraining orders which, while having little chance of being sustained, are likely to prove very embarrassing to the employers.

To date, resort to injunctions by labor has been exceptional. The most frequent use of this weapon has been made by "radical" unions, not affiliated with the American Federation of Labor. The Federation has steadfastly discouraged attempts to secure injunctions on behalf of labor. Doubtless, this is due to the fact that it would appear inconsistent to apply for injunctions, while condemning them on principle. Doubtless also, the attitude which Law and Labor has been taking toward injunctions has been influenced by the controversy over employers' injunctions. Like the American Federation of Labor, Law and Labor regards every application for an injunction by labor as an endorsement of the use of the same weapon by employers in labor disputes.

The fallacy of this argument seems to me to be quite clear. Labor can consistently argue that resort to injunctions by employers is unfair and unwarranted, and yet make use of the same weapon when occasion presents itself. This is not an endorsement of the principle of injunctions, but merely a counter- 
offensive-an administration to employers of a dose of their own medicine.

It is probable that in the future, labor will apply to the courts for injunctions much more frequently than it has in the past. Union officials and attorneys who have steadfastly counseled against the use of injunctions by labor are quite free to admit that there are situations in which such injunctions can be used very effectively. For the present, however, there is little likelihood that they will become as numerous as injunctions by employers, nor that they will play anywhere near so large a role in labor controversies.

\section{APPENDIX}

LIST OF INJUNCTION ACTIONS BY OR ON BEHALF OF LABOR AGAINST EMPLOYERS OR PUBLIC OFFICIALS

(1) Worthington v. Waring, 157 Mass. 421 (1892). Injunction against blacklisting refused on the ground that the remedy lies in an action in tort.

(2) Platt v. Philadelphia \& Reading R. R., 65 Fed. 660 (C. C. E. D. Pa. 1894). Injunction sought against the receivers of the defendant railroad company to prevent them from discharging employees affiliated with the Brotherhood of Railway Trainmen. The United States Attorney General Olney wrote a letter to Judge Dallas urging that this injunction be allowed, but it was refused nevertheless. Text of this letter in SEN. Doc. No. 190, 57th Cong. 1st Sess.

(3) J. A. Fay \& Egan Co. and American Tool Works v. Machinists, U. S. C. C., S. D. Ohio. A temporary injunction was issued on complaint of the employer against the union, April 3,1901. The union then filed a cross bill seeking an injunction against blacklisting. On July 24, 1901, both the employer's and the union's complaints were dismissed. Cincinnati Enquirer, April 4, July 17, 25, 27, 1901.

(4) Stone Cleaning \& Pointing Union v. Russell, 38 Misc. 513,77 N. Y. Supp. 1049 (Sup. Ct. 1902). An injunction sought against the breach of a trade agreement was denied upon the ground that an injunction will lio to enforce a labor contract only when the services are unique.

(5) Bcyer v. Western Union Telegraph Co., 124 Fed. 246 (C. C. E. D). Mo. 1903). An injunction against blacklisting sought by members of the Commercial Telegraphers' Union No. 3 of St. Louis was denied on the ground that blacklisting is legal.

(6) Glass Bottle Blowers' Ass'n v. George Jonas Glass Co., Camden, N. J., 1902. Injunction sought as a counter move to the injunction which figured in the reported case, 64 N. J. Eq. 644, 54 Atl. 567 (1903). This application was based upon the claim that the company guards were intimidating the strikers. The case apparently was never brought to trial. Newark News, Nov. 26, Dec. 1, 1902; N. Y. Journal, Nov. 28, 1902 ; Bridgeton News, Dec. 11, 1902.

(7) I'aiters' Union v. Omaha Business Men's Ass'n, Omaha, Neb., May, 1903, Judge Dickinson. Temporary restraining order allowed in counter complaint to employers' suit for an injunction, which prohibited all interference by the defendant with the Omaha labor unions. This order was dissolved upon a hearing. Omaha World-Herald, May 13, 26, 1903. 
(8) Injunction on behalf of the Denver labor unions, issued by District Judge Mrullins, against the Denver Citizens' Alliance, Mlay, 1903, prohibiting attempts to break up the unions. Omaha World-Herald, May 15, 1903.

(9) Atkins v. W. A. Fletcher Co., 65 N. J. Eq. 658, 55 Atl. 1074 (1903). An injunction sought on behalf of a machinists' union to prevent interference by the defendant company with union pickets was denied by the trial court and this decision affirmed in the reported case.

(10) United Mine Workers 2 Leiter, U. S. D. C., S. D. M., Judge Humphrey, 1904. An injunction, seeking to compel the defendant emplort: to let strikers go upon his premises to get their mail, was refused. Un.ted Mine Workers' Journal, Aug. 18, 1904.

(11) Tailors: Union v. Marnitz \& Co., Millwaukee Co., Wis., 1905. A temporary restraining order issued by a court commissioner enjoined the defendant employer from breaking his trade agreement with the union. It was dissolved after a hearing by Judge Ludwig on the ground that the closed shop contract in question was against public policy. Chicsgo Record-Herald, July 13, 1905.

(12) Lewitzky v. Independent Rag Workers, Sufolk Co, Hass., June, 1906. An injunction against blacklisting was sought in a cross-bill to the employer's suit for an injunction. It was never issued. Hassnchusers 8 LABOR BULLETIN No. 70, p. 138.

(13) Boston Machine Works Co. v. Machinists' Union, Essex Co., IFess., Nov., 1907. An injunction sought in cross-bill to prevent blacklisting and interference with union was dismissed on demurrer. ITASSACEUSETTS LABOR BULLETIN No. 70, p. 141.

(14) Enterprize Ass'n of Steam Fitters v. Bldg. Trades Employero' Ass'n, New York City, Justice Fitzgerald, 1910. This injunction prohibited coercion on the part of members of the defendant nssociation arninst dealing with the union. Machinists' Journal, IIay, 1910.

(15) Moving Picture Machine Operators' Protective Union, Local No. 108 v. Automatic Vaudeville Co., Sufiolk Co., Brass., 1912. Injunction cought to prevent the defendant from employing non-union men in violation of a trade agreement.

(16) Savage v. Potter, 159 App. Div. 729, 145 N. Y. Supp. 78 (1918). An action begun in 1911 by officers of the Carpenters' Joint District Council of New York City to restrain the American Anti-Boycott Association from representing its members in legal actions, premised upon the New Yorls statute prohibiting corporations from practicing lnv. The decision in the trial court was against the plaintiofs, on the ground that the damage sustained could be recovered through actions in tort. An appenl was taken to the Appellate Division, but in the end the case was dismissed. For an account of the earlier stages of this case, see The Carpenter, Iroy, 1913.

(17) Injunction on behalf of the Western Federation of Miners restraining certain mining companies from evicting strikers in the Michigan copper strike, issued by a state court early in the fall of 1913. REPORT OF THE EXECUTIVÉ BOARD OF THE WESTERN FEDERATION OF MINERS (Feb. 19, 1914).

(18) Western Fedcration of Miners v. Members of the Citizens' Allianee, C. C. Houghton County, Mich., Judge O'Brien. An injunction issued on Oct. 10, 1913, prohibited the defendants from threatening or intimidating the members of the union on strike in the copper country. Detroit Free Press, Dec. 11, 1913.

(19) Potter v. Mayer Shoe Co., Milwaukee, Wis. A temporary restraining order by Court Commissioner MIcElroy, Dec. 19, 1913, forbade the defendants from blacklisting striking shoe workers. Hearings on the injunction took place before Circuit Judge Ludwig in February, 1914. Tho 
action was dropped when settlements were made with the employers involved. There is a copy of the injunction in the Wisconsin Historical Library; other information was secured from W. B. Rubin, attorney for the union.

(20) Cornellier v. Haverhill Shos Manufacturers' Ass'n, 221 Mass. 554, 109 N. E. 643 (1915). Striking shoe workers at Haverhill, Mass., in the winter of 1913 , were denied an injunction against blacklisting and their claim for damages on the ground that the plaintiffs did not come into court with clean hands, as there had been some violence during the strike.

(21) United Shoe Workers' Union v. Brown Shoe Co. and Boot \& Shoe Workers' Local Union, C. C. St. Louis, Mo., March, 1914. The plaintiffs were denied an injunction to restrain the enforcement of a trade agreement between the two defendants for the exclusive employment of members of the last named union. Milwaukee Sentinel, March 3, 1914; A. F. of L. Weekly News Letter, April 4, 1914.

(22) Waitresses' Union No. 484 v. Philip Henrici Co., C. C., Cook Co., Ill., 1914. An injunction to break up a conspiracy of the Chicago Restaurant Keepers' Ass'n to destroy the waitresses' unions was sought in a crossbill to the employers' suit for an injunction against the striking waitresses. An injunction was denied to the union and granted to the employers on April 6, 1914. Complete records in the case were filed with the U. S. Commission on Industrial Relations.

(23) An injunction sought by the strikers at the Westinghouse Co. plant in Pittsburgh to require Sheriff Richards to remove his deputies from the strike zone was denied by Judge Evans on July 8, 1914, on the ground that no damage to any property of the complainants was alleged. New York Call, July 9, 1914.

(24) Owens v. Board of Education, Cuyahoga Co., Ohio, June, 1914. This was a taxpayers' action on behalf of the Cleveland Federation of Labor to prevent enforcement of a rule adopted by the Cleveland Board of Educntion to the effect that it would employ no teacher affiliated with an American Federation of Labor union. City Superintendent Fredericks was found guilty of contempt for violating the injunction, but this conviction was set aside by the Appellate Court in June, 1915, the case being reported in 60 Ohio L. Bull. 321.

(25) People ex rel. Fursman v. City of Chicago, 278 Ill. 318, 116 N. E. 158 (1917). This case began in 1915, when the Chicago Teachers' Federation secured an injunction restraining the Chicago Board of Education from enforcing a rule prohibiting teachers from belonging to any American Federation of Labor union. The injunction was sustained on appeal by the Appellate Division, but dissolved in the reported case by the Illinois Supreme Court, on the ground that the rule of the Board of Education was legal.

(26) An injunction was secured by striking machinists of the Allis-Chalmers Co., West Allis, Wis., restraining the chief of police of West Allis from participating in the selection of juries in criminal cases growing out of the strike. A. F. of L. Weekly News Letter, Oct. $T, 1916$.

(27) San Antonio Fire Fighters' Local Union No. 84 v. Bell, 223 S. W. 506 (Tex. Civ. App. 1920). In this case, the Texas Court of Civil Appeals affirmed a decision denying an injunction sought against the city commissioners of San Antonio to restrain them from disrupting the firemen's union. The decision was based upon the premise that the union had no property interests at stake, and therefore could not bring suit in its own name; and also, that the city might lawfully refuse to employ union firemen.

(28) Ryan v. Tuttle-Jones Co., Superior Court, Essex Co., Mass., (1921) 
$3 \mathrm{LAW}$ AND LABOR 139. An injunction sought by the officers of Joint Council No. 1, United Shoe Workers of America, to compel the defendant company to operate a union shop as provided in a trade agreement between the Joint Council and the Lynn Shoe Manufacturers Ass'n, was denied by the court, which instead issued an injunction against the Joint Council as sought by the defendant in a cross-bill.

(29) Schwartz v. Diziscoll, Circuit Judge, 217 Miich. 384,186 N. W. 522 (1922). This case was begun in April, 1921, as a cross-bill to an injunction sought by a Detroit cigar manufacturer against the Cigar Malkers' International Union, the cross-bill being premised upon the claim that the employer was violating a trade agreement. Judge Driscoll of the Circuit Court of Wayne Co., Mich., held for the union, allowed the injunction which it sought, and denied the injunction sought by the employer. In the reported case, however, the Michigan Supreme Court reversed the decision of the trial court, dissolved the injunction issued to the union, and, in Schwartz v. Cigar Makers, 219 Mich. 589, 189 N. W. (1922), allowed the injunction sought by the employer.

(30) United Mine Workers' Dist. No. 24 v. Coal Opcrators, C. C. Franklin Co., $\mathrm{Ml}$. An injunction prohibited the coal operators from interfering with the collection of union dues through the check-off system. Industrial Nerro Survey, Oct. 22, 1921.

(31) Schlesinger v. Quinto, Supreme Court, New York Co., N. Y., Nov. 28,1921 . An injunction allowed to the Internationsl Ladies Garment Workers' Union against the Cloak, Suit \& Skirt Mrgs' Ass'n, to prevent breach of a trade agreement, was made permanent Jan. 1922, and afirmed by the Appellate Division in 201 App. Div. 487, 194 N. Y. Supp. 401 (1st Dep't 1922), one judge dissenting.

(32) Leveranz v. Cleveland Home Brewing Co., Court of Common Plens, Cuyahoga Co., Ohio (1922) 4 LAW AND LABOR 220. An injunction on behalf of the International Brotherhood of Firemen \& Oilers' Locals 8 and 13 against eight Cleveland breweries to prevent breach of a trade agreement.

(33) Welsh v. Vinton Colliery Co., Court of Common Pleas, Cambris Co., $\mathrm{Pa}$., June 17, 1922. An injunction was issued at Edensburg, $\mathrm{Pa}$., on complaint of a representative of the American Civil Liberties Union and of officers of United Mine Workers' District No. 2, restraining the defendant company from interfering with efforts to organize its employees. The injunction was set aside on the next day by a justice of the Pennsylvania Supreme Court, upon a writ of supersedcas. New York Times, June 25, 1922. Upon trial of the case, the Court of Common Pleas, on Jan. 8, 1923, dismissed the complaint as being bad because multifarious. (1923) $5 \mathrm{LnW}$ AND LABOR 36.

(34) Noonan v. Gordon, Sup. Ct. D. C., Judge Bailey. An application for an injunction on Sept. 7, 1922, by officers of the International Brotherhood of Electrical Workers to restrain the marshal and the district attorncy of the District of Columbia from enforcing the injunction issued at Chicago, on motion of the Attorney-General of the United States, in the case of United States v. Railway Employees' Dep't, A. F. of L. The motion was denied without prejudice, to await disposition of the Chicago case. Chicago Tribune, Sept. 8, 1922.

(35) Howard Peterson v. United Engraving Co., District Court, Ramsey Co., Minn., Judge Lewis, 1922. An injunction sought by the St. Panl photo engravers' union to prevent breach of a trade agreement was refused, on the ground that the agreement lacked mutuality. Duluth Labor World, Feb. 4, 1922.

(36) An injunction secured in April, 1922, by forty striking miners, tenants of the Kettle Creek Coal Co., at Lockhaven, Pa., prohibiting this com- 
pany from evicting them from company houses, was subsequently dissolved by Judge Beard of the Court of Common Pleas of Cambria Co., Pa. New York Times, April 20, 1922; Federated Press Bulletin, April 29, 1922.

(37) Injunction issued by Justice Tanner at Providence, R. I., restraining B. B. \& R. Knight, Inc., from evicting striking employees from company houses, June 5, 1922. New York Times, June 6, 1922.

(38) Franklin Press v. Detroit Typographical Union No. 18, C. C., Wayne Co., Mich., May 13, 1922. (1922) 4 LAW AND LaBor 166. The employer's crossbill to an injunction suit to require the employer to abide by an arbitration award was decided against the union.

(39) Injunction by Circuit Judge Coldwell at Newport, Ky., March 16, 1922 , prohibiting the state militia from interfering with strikers' meetings or intimidating strikers. (Jan. 1923) AMERICAN FEDERATIONIST.

(40 \& 41) Pennsylvania System Board of Adjustment of the Brothcrhood of Railway Clerks v. Pennsylvania Railroad; Pennsylvaria Railroad Systom \& Allied Lines Federation No. 90 v. Pennsylvania Railroad, U. S. D. C., E. D. Pa. Injunctions sought to compel the defendant railroad company to deal with the railroad shop crafts' unions, as directed by the Railroad Labor Board, were refused by the district court. (1924) 6 LAW AND LABOn 13. This decision was affirmed, upon a rehearing, in $296 \mathrm{Fed} .220$ (E. $\mathrm{D}$. $\mathrm{Pa}$. 1924), and by the Circuit Court of Appeals in 1 F. (2d) 171 (C. C. A. 3d, 1924), and by the United States Supreme Court in 267 U. S. 203, 219. 45 Sup. Ct. 307, 312 (1925).

(42) United Mine Workers of America, Dist. No. 17 v. Chafin, 286 Fed 959 (S. D. W. Va. 1923). An injunction sought to prevent the sheriff of Logan Co., W. Va., from beating up or otherwise illegally interfering with union organizers was denied on the ground that the court larked jurisdiction, as all the parties were citizens of West Virginia.

(43) Federated Shop Crafts v. Great Northern Ry. and T'he Great Nortlsern Ass'n of Shop Crafts Employees, D. C. Ramsey Co., Minn. An application was filed in July, 1923, to prohibit interference with the members of the plaintiff unions to compel them to join the company union, and a temporary injunction was allowed after hearing, Sept. 12, 1923. Minneapolis Journal, July 25, 1923; Minnesota Daily Star, Sept. 13, 18, 1923.

(44) Goyette v. C. V. Watson Co., 245 Mass. 577, 140 N. E. 285 (1923). A suit for injunction and damages by the Shoe Workers' Protective Union to compel the Watson Co. to live up to a closed shop agreement resulted in an interlocutory decree for the union April 15, 1922, but this was dissolved by the Massachusetts Supreme Court in the reported case, on the grounds that courts will not enforce a closed shop contract and that the union could not bring suit for its members.

(45) Lovely v. Gill, 245 Mass. 577, 140 N. E. 285 (1923). In this case, the Massachusetts Supreme Court overruled a demurrer to a suit brought on behalf of the Boot \& Shoe Workers' Union against the Triangle Shoe Co. and the Shoe Workers' Protective Únion, to prevent breach of a trado agreement by the Triangle Shoe Co. The case was thereafter dismissed by agreement, as the difficulty had been settled. Information secured from H. B. Ehrmann, attorney for the union.

(46) Keegan v. Board of Commissioners of the Port of New Orleans, 154 La. 639,98 So. 50 (1923). In this case the Louisiana Supreme Court refused the longshoremen's unions an injunction directed against an order of the New Orleans port commissioners forbidding anyone from being on the wharves, which was enforced so as to prevent picketing during a strike.

(47) Carpenters' Union of Chicago v. Citizens' Committee, 333 Ill. 225, 164 N. E. 393 (1928). A suit filed in October, 1922, to enjoin interference by the Citizens' Committee with contractors who dealt with the union re- 
sulted in denial of an injunction on the ground that the union had been guilty of violence, although the court also found that the defendants' conduct had been unlawiul. (1922) 4 LAW AND LABOR 59. This decision was affirmed by the appellate court, but was reversed by the Illinois Supreme Court in December, 1928, and the injunction sought by the union was allowed.

(48) Philadelphia Electrotypers' \& Finishers' Union No. 72 v. Bethlohem Plate Co., Ct. of Comm. Pl. Philadelphia Co., Pa., 1924. In this case, the union sought an injunction prohibiting the defendant non-union employer from employing a union member who had signed a contract with the union not to work for any non-union employer. The case was dismiesed because the contract in question had expired at the time of the trial. (1926) 75 U. OF PA. L. REv. 523.

(49) Thomas v. City of Indianapolis, 195 Ind. 440, 145 N. E. 550 (1924). This case involved an attempt to enjoin the enforcement of an anti-picketing ordinance adopted by the city council of Indianapolis in 1910. The injunction was allowed by the trial court but dissolved by the Indiana Supreme Court in the reported.case, on the ground that the ordinance in question was legal.

(50) Street v. Shipowners' Ass'n of the Pacific Coast, 299 Fed. 5 (C. C. A. 9th, 1924). An application for an injunction by the International Seamen's Union to compel the defendants to discontinue their "registration book" method of hiring seamen, which the union claimed resulted in the blacklisting of its members, was denied by the trial court and this decision affirmed in the reported case by the Circuit Court of Appeals.

(51) Tilbury v. Oregon Stevedoring Co., 8 F. (2d) 898 (D. Ore. 1925), affd, 7 F. (2d) 1 (C. C. A. 9th, 1925). In this case, an injunction and damages were sought by members of the longshoremen's unions of Portland, Ore., to break up the "hiring hall" system of hiring longshoremen, which was claimed to be a method of blacklisting union membara The injunction was denied on the ground that no interference with foreign or interstate commerce was established and that therefore the federal courts did not have jurisdiction.

(52) Amalgamated Clothing Workers v. Irtornational Tailoring Co., Sup. Cr., New York City, Judges McGoldrick and Church, July-August, 1925. An application for an injunction to prohibit the defendant employer from conspiring to destroy the union, sought as a counter move agninst the employers' petition for an injunction against the union, was not allowed. New York Times, July 25, Aug. 13, 1925.

(53) Lovinger \& Schwartz v. Joint Board of the Cloak, Suit, Slirt \& Dressmakers' Union, Ct. of Comm. Pl., Cuyahoga Co., Ohio, (1925) 7 LAT AND LABOR 120. Injunction sought by employer to prevent the unions from interfering with employer-employee contracts. The court allowed an injunction to the employer without referring to the individual non-union contracts.

(54) Polk v. Cleveland Railway Co., 20 Ohio App. 317, 151 N. E. 808 (1925). An injunction sought on behalf of the Amalgamnted Ass'n of Street \& Electric Railway Employees, Local No. 268, to compel the defendant to observe an arbitration award, was denied, on the ground that this award was made under a trade agreement providing for a closed shop. The Ohio Supreme Court refused to reviev this decision. A. F. of L. IEGAL INFORMATION BULLETIN No. 12 (1925) 13-17.

(55) Pearlman v. Millman, Sup. Ct., Suffolk Co., Mass., July 3, 1925, (1925) 7 LAW AND LaBOR 286. An injunction secured on behalf of Fur Workers' Union No. 30 of Boston, prohibiting an employer from brealking a trade agreement. 
(56) American Civil Liberties Union v. Nimmo, Bergen Co., N. J., ViceChancellor Bentley, May 1926. An injunction in the Passaic textilo workers strike was taken out against the sheriff of the county to prevent interforence with a strike meeting at which John Haynes Holmes had been scheduled to speak. Chicago Tribune, May 1, 1926; Nation, May 12, 1926.

(57) Berkhammer v. Cleveland \& Morgantown Coal Co., at Morgantown, W. Va., Circuit Judge Lazzelle, June, 1926. An injunction sought on behalf of the United Mine Workers to compel four coal companies to observo the Jacksonville agreement with the union, said to have been suggested by Herbert Hoover, was denied on the ground that the trade agreement was unenforcible. (1926) 8 LAW AND LABOR 217.

(58) Anderson v. Ship Owners' Ass'n of the Pacific Coast. An injunction sought under the Sherman Anti-Trust Act to break up the "hiring hall" method of selecting employees. The trial court and the Circuit Court of Appeals held that no case under the Sherman Act was presented in the pleadings. 10 F. (2d) 96 (C. C. A. 9th, 1926). But the Supreme Court overruled these decisions and sent the case back for trial. 272 U. S. 359, 47 Sup. Ct. 125 (1926). This resulted in a decision for the defendants, which was later affirmed by the Circuit Court of Appenls. 27 F. (2d) 163 (N. D. Cal. 1928), aff'd, 31 F. (2d) 539 (C. C. A. 9th, 1929).

(59) An injunction was secured on bahalf of the Amalgamated Ass'n of Street \& Electric Railway Employes against county and policy officers of the City of Indianapolis, Superior Court, Marion Co. Toledo Union-Leader, June 18, 1926.

(60) McGrath v. Norman, 221 App. Div. 804, 223' N. Y. Supp. 288 (2d Dep't 1927); (1927) 9 LAW AND LABOR 155 . This injunction was issued on April 30, 1927, by Judge Mitchell of the Supreme Court, Queens Co., $N$. Y., at the instance of a plumbers' union, against an association of master plumbers, to restrain the calling of a lockout, alleged to be in violation of a trade agreement. This injunction was dissolved upon trial, on the finding that the union had first violated the agreement; and this decision was affirmed by the Appellate Division in the reported case.

(61) Moran v. Lasette, 221 App. Div. 118, 223 N. Y. Supp. 283 (1st Dep't 1927); (1927) 9 LAW AND LABOR 142. An injunction was allowed in this case by Supreme Court Justice Churchill of Bronx Co., N. Y., to Plumbers' Union No. 463, restraining a masters' association from locking out mombors of the union. The injunction was dissolved in the reported case by the Appellate Division.

(62) Brotherhood of Railway \& Steamship Clerks v. Texas \& New Orleans R. R., 24 F. (2d) 426 (D. Tex. 1928); 25 F. (2d) 873, 876 (D. Tex. 1928) (Judge J. C. Hutcheson, Jr.) ; 33 F. (2d) 13 (C. C. A. 5th, 1929); (1927) 9 LAW AND LABOR 243.

(63) Paruto v. Espey, D. C. Las Animas Co., Colo., Jan. 4, 1928, (1928) $10 \mathrm{LAW}$ AND LABOR 48. An injunction on behalf of striking I. W. W. coal miners restraining the mayor and other officers of Trinidad from interfering with the strike headquarters, but also forbidding the use of these headquarters for sleeping purposes.

(64) Goldman v. Cohen, 222 App. Div. 631, 227 N. Y. Supp. 311 (1st Dep't 1928) ; (1928) 10 LAW AND LABOR 63 . An injunction was issued by Supreme Court Justice Crain in New York City, Jan., 1928, on behalf of the International Pocketbook Workers' Union, to restrain the firm of Cohen Bros. \& Berman from removing its plant to Lynbrook, Long Island, in order to get around an unexpired trade agreement. The injunction was affirmed in the reported case by the Appellate Division.

(65) Federation of Express Workers v. American Railway Express Co., U. S. D. C., S. D., New York, Judge Mack, April 1928. An injunction was 
refused which was sought to compel the defendant to discharge members of the Brotherhood of Railway Clerks and to resume relations with the plaintiff union. Labor, May 5, 1928.

(66) Nolan r: Farmington Shoe-Mfg. Co., 25 F. (2d) 906 (D. Mass. 1928). Here, an injunction was denied to the Shoe Workers' Protective Union to restrain the defendant from signing nembers of the union to individual contracts obligating them to do nothing to induce this company to give up its open shop plan after these union members had entered into contracts with the union in which they agreed to sign no contract requiring them to give up their union membership. The court's decision was based upon the theory that there was nothing inconsistent in a union man's signing both contracts.

(67) Goldman v. Wile Importing Co., Sup. Ct., New York City, July 31, 1928, (1928) 10 LAW AND LABOR 207. In this case, an employer had removed his factory from New York to Springfield, Mlass., to avoid a trade agreement. An injunction on behalf of the International Pocketbook: Workers' Union forbade breach of contract and employment of non-union men.

(68) Goldman v. Rozenzweig, Sup. Ct., Nev York City, Aug. 1928, (1928) 10 LAW AND LABOR 207. This was another injunction on behalf of the International Pocketbook Workers' Union against a partnership which incorporated and then attempted to operate on a non-union basis.

(69) Seattle High School Chapter No. 200, American Fedcration of Teachers v. Sharples, Sup. Ct., Kings Co., Wash., May 1928, (1928) 10 LAW AND LABOR 212. The outcome of this case was the refusal of an injunction against the enforcement of a rule of the Seattle Board of Education against the employment of teachers belonging to the union.

(70) Riffkin v. Mendelbaum, Sup. Ct., New York City, April 14, 1928, (1928) 10 LAW AND LABOR 142. An injunction premised upon a trade agreement prohibiting the defendant from employing any but union waiters.

(71) United Mine Workers' Dist. No. 11 v. Logsdon, Sup. Ct., Marion Co., Ind., Judge Hay, Feb.-March, 1929. An injunction was refused the union against the receiver of the Knox Consolidated Coal Co. to restrain him from reducing wages below the scale set in an unexpired trade agreement. Information from Henry Warrum, attorney for the union.

(72) An injunction sought on behalf of the United Textile Workers against city officials of Gastonia, N. C., to enjoin the enforcement of an ordinance prohibiting strike parades was denied by Judge Sink of the Mecklenburg Co., Superior Court, May 14, 1929, on the ground that the ordinance was valid. Baltimore Sun, Mray 3, 15, 1929.

(73) Cassidy v. Bldg. Trades Employers' Ass'n of New Yorle City, Sup. Ct., New York City. An injunction was sought on behalf of the cement workers' union, by Justice Gavegan, May 14, 1929, to prohibit a lockout of 75,000 building trades workmen. The injunction action was withdrawn when the dispute was settled May 17, 1929. New York Times, May 15, $18,1929$. 